\title{
MRC1 wt Allele
}

National Cancer Institute

\section{Source}

National Cancer Institute. MRC1 wt Allele. NCI Thesaurus. Code C104634.

Human MRC1 wild-type allele is located in the vicinity of 10p12.33 and is approximately $102 \mathrm{~kb}$ in length. This allele, which encodes macrophage mannose receptor 1 protein, plays a role in mediating endocytosis of glycoproteins by macrophages. 